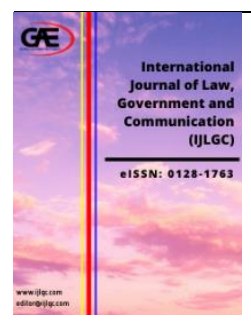

\author{
International Journal of Law, Government and \\ Communication (IJLGC) \\ Journal Website: http://ijlgc.com/ \\ eISSN: 0128-1763
}

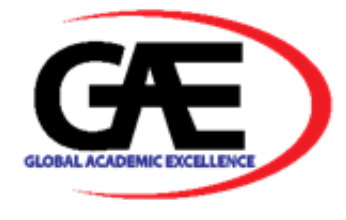

\title{
ETHICS AND LAW ON FLAMING ON YOUTUBE: A PERCEPTION FROM THE FLAMERS ON YOUTUBE
}

\author{
Norizah Aripin $^{1}$, Sabrina Mohd Rashid ${ }^{2}$, Awan Ismail ${ }^{3}$, Revathy Amadera Limgam ${ }^{4}$
}

1 School of Multimedia Technology and Communication, Universiti Utara Malaysia, Malaysia Email: noryzah@uum.edu.my

2 School of Multimedia Technology and Communication, Universiti Utara Malaysia, Malaysia Email: sabrina@uum.edu.my

3 School of Multimedia Technology and Communication, Universiti Utara Malaysia, Malaysia Email: awan@uum.edu.my

4 School of Multimedia Technology and Communication, Universiti Utara Malaysia, Malaysia Email: revathylingamphd@gmail.com

\section{Article Info:}

\section{Article history:}

Received date: 24.03 .2020

Revised date: 27.04 .2020

Accepted date: 05.05.2020

Published date: 10.06 .2020

\section{To cite this document:}

Aripin, N., Rashid, S. M., Ismail, A., \& Lingam, R. A. (2020). Ethics and Law on Flaming on YouTube: A Perception from the Flamers on YouTube. International Journal of Law, Government and Communication, 5 (19), 54-67.

DOI: $10.35631 / I J L G C .519004$.

\begin{abstract}
:
Flaming activity on YouTube is a part of cyber-bullying in social media. Today, the YouTube website has been labelled as a page that contains a lot of flaming. It is claimed that flamers debate and comment on the issues on YouTube without taking ethics and law into consideration. The design of this research is to study the views and opinions on law and ethics in the use of YouTube from the flamer's point of view. This study uses a qualitative methodology. Face-to-face interviews are conducted by involving five informants who are the flamers on YouTube. Thematic analysis is used to analyse the data. The findings show that informants have an understanding of certain ethics before flaming on YouTube. However, almost all the informants have a lack of knowledge of the laws implemented on cybersecurity in Malaysia especially on flaming on YouTube. The findings of this study conclude that informants practice a certain type of ethics when accessing YouTube, but lack awareness of the laws implemented on cybersecurity when commenting on the site.
\end{abstract}

Keywords:

Ethics, Laws, Flaming, YouTube

\section{Introduction}

Some Internet users regardless of their age are willing to misuse the Internet by discommoding other users deliberately or unintentionally which leads to cyber-bullying. How common is 
cyber-bullying in Malaysia? According to a newspaper article from The Star, a total number of 529 cases has been reported in 2016. A whopping number of 1524 cyber-bullying cases has been recorded within the year 2012 to 2016 (Thye, 2017). Cyber-bullying in Malaysia is far more serious from what has been reported as many victims choose to remain silent due to various reasons. According to MyCert, a Malaysian computer emergency response team, a total number of 260 cyber-harassment cases have been submitted to them in the year 2019 from the month January to December (MyCERT Incident Statistics, 2019). Based on the statistics found, it is proven that cyber-based crime is increasing and in a crucial state for the time being. However, there is no record on the issue of flaming specifically in which it indicates that there is a need on studying this issue in Malaysia to ensure the safety of MyCert and Cyber Security data in the future.

In recent years, YouTube has been labelled as the number one website with the greatest number of flames (Khan, 2017). Flames on YouTube include visual images and it is an important aspect to be studied. The materiality of visual information on YouTube gathers attention to the researcher and the element of excitement includes how visual information is processed and presented through understanding the meaning of visual images embodied on YouTube. Specifically, visual images provide meaning and analysis on photos and visual content such as objects, texts, or faces upon the access of the site. According to Boyd (2006), YouTube was initially started as a video sharing platform, but it also offers features like being a user's profile and a channel to chat thus making a platform to make new friends.

A preliminary study was done by Revathy (2015) to find the focus on the usage of YouTube. During the process, she picked videos from all the video categories on YouTube to study the diverse nature of YouTube. Upon the thorough examination on each category, she had come across a variety of differences in every category of videos studied which is people and blogs, autos and vehicles, comedy, education, entertainment, film and animation, gaming, how-to and style, music, news and politics, non-profits and activism, pets and animals, science and technology, sports and travel and events. A study done by Siersdorfer, Chelaru, and Nedjl (2010), had studied YouTube according to its video categories but the focus of the study was to find the comments' rating, the acceptance of comments, and its polarizing content. The results of both these studies indicate that flames are present in all the categories of YouTube.

The Malaysian government has developed the information and communications technology (ICT) industry which includes social media and this development benefits the community. However, the use of YouTube has given the freedom of expression in Malaysia and sparked controversy over participation via comments published through video images on YouTube. There are plenty of derogatory comments touching sensitive issues. The Malaysian Communications and Multimedia Commission monitors YouTube upon its controversies and sensitive issues. In May 2013, some sensitive and critical YouTube videos were blocked by MCMC to prevent abuse on the video and the issues discussed (Sinar Project, 2016).

According to Sinar Project (2016), more than 17 million Malaysians uses the Internet, with a $61 \%$ Internet penetration rate, proving the rapid growth of social media usage within the country. Internet users in Malaysia are mostly 21 to 40 years old and among the active social media sites are Facebook, Twitter, and YouTube.

Issues on censorship practices on the Internet by the government are still an issue of debate. According to Forum Asia (2012a), the Malaysian government is controlling the Internet even though it will not ensure Internet censorship in the Bill of Guarantees. The MCMC has 
proposed steps to prevent some of the file retrieval websites, which violates the provisions that deal with pirated content under Section 41 of the Copyright Act 1987. MCMC has also blocked Malaysia Today's website where it comprises too many issues on Malaysian political controversy (Forum Asia, 2012a).

Malaysian Communications and Multimedia Commission Act of 1998 (Malaysia, 2006) introduced and reinforced the act which states that "to implement and enforce the provisions of the communications and multimedia law, to regulate all matters relating to communications and multimedia law", "to supervise and monitor communications and multimedia activities" and "to encourage and promote self-regulation in the communications and multimedia industry". Those were the examples of quotes that prove that MCMC has all the rights and has taken action against those who misuse social media sites (Forum Asia, 2012b).

Thus, this research will focus on the real situation on the YouTube platform where the implementation of the legal acts will be looked upon. While freedom of the speech is encouraged, there are still limitations that YouTube users need to know and acknowledge when accessing the site.

The design of this research is to study the views and opinions of the flamers on YouTube on the issues of ethics and law.

\section{Literature Review}

\section{Definition of Flaming}

There are several definitions of flaming based on past researchers' views. Steele et al. (1983) defined flaming as to speak rapidly or incessantly on an uninteresting topic or with a patently ridiculous attitude. Reinig et al. (1997) stated that flaming as verbal attacks intended to offend either persons or organizations. Meanwhile, Moor (2010) defined flaming as displaying hostility by insulting, swearing, or using otherwise offensive language. In short, flaming is an interaction that illustrates the lack of politeness, insult, and disrespect amongst Internet users. This statement is consistent with Kayany's (1998) view, flaming can be defined hostile emotional expression is directed at others, contrary to the criticisms directed at ideas and opinions. O'Sullivan et al. (2003), explains that the process of flaming includes the creation, transmission, and interpretation of messages viewed from various perspectives as breaking the norms. Discussion on first world issues such as politics, religion, and philosophy, or issues polarizing sub-populations. Based on flaming definitions, it can be concluded that flaming activity is an open communication expression that does not follow certain norms in social media.

\section{Ethics in Social Media}

Ethics is the rule of conduct or moral principle that guides the appropriate action for a particular situation. Bourke (1966) defines ethics as a human reason that enables them to use their thinking to determine and distinguish 'good' rather than 'bad' for things related to their lives. Today, the media is growing rapidly with intense new forms hence changing the ethics of its users. According to the Stanford Encyclopedia of Philosophy (2015), social media such as MySpace, Twitter, YouTube, and Facebook have changed the political, social individual, and institutional information of the world. The latest social media ethics should take privacy concerns, identity and community, friendship, virtue, good life, and democratic freedom, cybercrime, and meta-ethical issues related to ethical information into account. The following are the descriptions of the concepts of social media ethics. 
First is privacy, personal identity, and community aspect. Elgesem (1996) defines privacy through information. Tavani (2007) states that privacy is restricting access to information or contextual integrity that needs to be reviewed through Facebook, Twitter, and other social media privacy practices (Nissenbaum, 2004). Social media constitutes a new ethical space that works as a real and virtual identity and community of individuals to build interactions. Bakardjieva and Gaden (2012) defines social media as 'self-technology' to facilitate relationship building and personal identity achievement. Social media also facilitates the development of norms and moral practices (Parsell, 2008).

Second concept is friendship, virtue, and good life. Social media friendship builds a virtual friendship between individuals online. According to Cocking and Mathews (2000), online friendship forms 'as good as the real thing' to further 'face to face' friendships. Online friendship may be more obvious than offline, gives the feeling of secure because of physical distance and asynchronous written communications during the information exchange (Briggle, 2008).

Virtue and a good life are also related to social media ethics. These includes negative actions such as privacy violations, copyright, and others (Pak-Hang Wong, 2010). The choice of technology that needs to be taken into account are the goodness of welfare and good life that ensures its use in prudent ways. The scope of the research needs to be expanded by conducting interpersonal ethics research on social and the wisdom of social media usage (Spence, 2011; quoted from Stanford Encyclopedia of Philosophy, 2015). Other research on the intellectual wisdom and courage of social media users are done to provide moral goodness such as honesty, patience, justice, loyalty, charity, and empathy to educating social media users (Wong, 2012; Vallor, 2010; Stanford Encyclopedia of Philosophy, 2015) and cyber law enforcement.

The third concept is the social media ethics of public discussion or public discourse, freedom, and democracy in the public sphere. The discourse of ethics and democracy are common in public (Ess 1996 \& 2005; Dahlberg 2001; Bohman 2008). According to Habermas (1992/1998), the Internet promotes or impedes rational public exercise for freedom of expression. The Internet breaks the public sphere by promoting the creation of open-minded information. This will promote extremism and unconstraint, and create democracies with freedom of expression in social media (Sunstein 2008). Social media use for political activism and authoritarian regime such as Facebook and Twitter are platforms of revolution in North Africa, Egypt, and Tunisia (Marturano 2011; Frick \& Oberprantacher 2011).

The fourth concept is cybercrime. Abuse of social media has created 'cybercrime'. These include cyberbully, cyber-harassment, identity theft, copyright infringement, and others. The role of cyber security organizations are to investigate cybercriminal misconduct and cyber law enforcement. Social media users should be subject to legal action in the event of cybercriminal misconduct. The government is also working to record online Internet activity and enforce cyber law to ensure public and national security (Friedersdorf, 2015).

The fifth concept is about metaethical in social media. Metaethical defined as the ethical form of social media use (Tavani 2005; Moor 2008). These include the forms of the classical tradition of ethics such as utilitarianism and virtue ethics that have enough resources to explain the implications of social media ethics. According to Light, McGrath, and Gribble (2008) and Skog (2011), media ethics relates to the etiquette of disclosure as also suggested by Philip Brey (2000). These ethics are intended to look at the analysis of how certain moral values are 
embedded in specialized technology and enable the exposure of unclear technology trends to form moral practices. Ess (2006) suggests that a new "global information ethics" needs to be seen now and in line with the latest information technology. Other researchers have suggested that social media ethics need to be renewed and given attention to new ethics such as care or feminist ethics (Hamington 2010; Puotinen 2011), virtue ethics (Vallor 2010), and pragmatism ethical approaches (Van den Eede 2010).

\section{Laws in Social Media}

Law is a regulatory system enforced by government institutions to regulate users' behavior. The law is a system made by the legislature to regulate and ensures that individuals or communities comply with national requirements following legislation (Oxford University Press, 2018). Cyber law is a legal area of civil while criminal law involves Internet transactions. It includes issues related to communication and information such as freedom of speech, access to general information, and protection of intellectual property rights (Computer Hope, 2018).

According to Elpina, Henry Aspan, and Solly Aryza (2018), freedom of expression in social media is limited by content prohibited in the ITE Act (Law Number 11 of 2008 Information and Electronic Transaction Act). This Act was introduced because of the impact of cyberbullying development by teens on social media. It also aims to prevent teenagers from acting on legal counselling and cultivating moral values to students. Langos (2013) suggests that the law eradicate cybercrime needs to be considered by policy makers or working on the definition and concept of cyberbullying and crime. Besides, the juvenile justice system to bullying cybercriminals needs to be realized which may involve youth.

Meanwhile, Rost, Stahel, and Frey (2016) pointed out that digital society is growing and adapting to the changing digital environment of interaction. As such, the enforcement of future digital norms will increase. Regular abolition of anonymous names online and the introduction of real name policies are able to reduce online intrusion in social media. The act as implemented in South Korea in the validation of the Real-Name Authorization Act in 2007 aimed at reducing aggressive comments for a particular user community (Cho \& Kim, 2012).

In Malaysia, the government plays a big role in controlling the media. Internet penetration and social media have helped Malaysia to keep track of developments in other developed countries. As a multicultural country, racial harmony is the responsibility of the government. The establishment of the Printing Presses and Publications Act 1984 (PPPA) (Amendment 2012), the Film Censorship Act 2002 (Amendment 2006), the Broadcasting Act 1988 (Repealed by Communications and Multimedia Act 1998), the Communications and Multimedia Act 1998 (CMA) (Amendment 2006), and media ownership control helps control media in Malaysia. Social and new media are also subject to control through methods such as Internet control, blocking and filtering, and content removal (Saodah Wok \& Shafizani Mohamed, 2017).

Therefore, social media users need to be cautious and careful when sending messages or web page files. Legal action will be taken on the abuse social media such as sending defamatory messages or infringing intellectual property rights (FindLaw, 2018).

\section{Methodology}

To answer the research objectives of this research, the qualitative method which is the in-depth interview method was implemented. To emphasize the focus on people's subjective experiences and interpretations in terms of ethics and laws on flaming on YouTube, the usage of purposive sampling method was done. This sampling method involves people who expresses negative 
comments on the column/commentary on the YouTube Malaysia video. They are known as flamers. The researcher sends a private message to the flamers through YouTube inbox to conduct a face-to-face interview and a number of five flamers were chosen for this study. According to Creswell (2012), the relation to the size of a qualitative research sample for a specific purpose indicates that "to study a few individuals or a few cases" (pg. 209). Creswell (1998) also added the small number of the sample between four to ten people is used when indepth cases are to be reported. The number relates to the question or the type of qualitative approach used, for this research, five interviews were adequate to reach the objective of the research.

Unstructured interview pattern were used for this study. The interview questions did not follow any guidelines (Best \& Khan, 2003; Creswe11, 2007). The question focuses on ethics and regulations on the use of the YouTube from the flamers' point of view. Face-to-face interviews were conducted for those who are available for an interview session after a mutual agreement on the venue and date. Face-to-face interviews enable the researcher to obtain a more significant data, where elements like body language of the informants can be taken into account, unlike other mediums. In this study, interview sessions involving five informants whom are the flamers on YouTube have provided insights into reaching the research' objective.

Firstly, the informants are required to complete the consent form as the consent and permission to engage in this study. This act also promises that their interview results will be used solely for this study and will not be revealed to others. The name of the informants is kept confidential at all times to protect the personal data and privacy of informants. To answer the research objectives, in-depth interviews were done which includes intensive individual interviews or meeting the number of participants' which limits to explore specific views, thoughts, and circumstances. According to Best and Khan (2003), interviews are an essential way to obtain a clear and sustained data from the informants through oral information. There are also two independent coders who are specializing in social media in the area of flaming hired to assess the themes for the in-depth interviews conducted.

This study uses thematic analysis to analyse the data obtained. This analysis is carried out via line-by-line coding on the results of the data of the study. Researchers obtained data collection through a simple idea based on data information (Creswell, 2007). Ryan and Bernard (2000) stressed that thematic analysis is the core foundation and basic to qualitative research and should be mastered by the researchers to obtain the required data properly. They also stated that the thematic coding process is a major analysis of qualitative research.

The thematic analysis is best used for this study because of its flexible nature and also provides data that can be easily understood by the readers. The type of thematic analysis that will be implemented in this study is the inductive type where it uses the bottom-up approach. The inductive approach will help the researcher to group data into themes and sub-themes according to the research data designed.

The phases of the thematic analysis that were utilized for this particular study is the phase of processing the initial data from the interview and content analysis, generate initial codes, selecting themes and reviewing them, defining and naming the themes and finally producing the reports in the most productive way possible. With this in regard, the report written has a more systematic, reader-friendly, and easily understandable structure. 


\section{Findings and Discussion}

\section{Findings on Ethics from the Perspective of Flamers on YouTube}

The results of this study discuss three themes, namely ethical consideration upon commenting on YouTube, 'do's and don'ts' upon commenting on YouTube and awareness on the laws implemented in Malaysia on cyber security.

\section{Theme 1: Ethical Consideration upon Commenting on YouTube}

Ethics alludes to very much-established norms of good and bad that exhort what people should do, for the most part regarding rights, commitments, and advantages to society, reasonableness, or particular ideals. Besides, ethics also alludes to the investigation and improvement of one's moral benchmarks. It is reasonable why individuals would trust morals manages religious convictions, emotions, and societal weight because these things tend to mist the moral answer in specific circumstances, particularly on the web and assuredly concerning online networking (Kucuk, 2015).

The informants of this research questioned on wheatear they are mindful of the ethics when it comes to commenting on YouTube. All the informants have a different point of view on what ethics mean on social media and their answers appear to be very interesting. The following are the answers to the informants.

'Yes, I do keep in mind that I have to behave ethically when I do things but sometimes when you couldn't control your feelings, couldn't control your emotions and anger, you will never think about all that. You just say it out whatever you want to say and I believe that people who flame if they are mindful about ethical, ethics, they will never flame.'

(Informant 1)

'When I watch, for example, The Voice, I like this singer and then I think he can do better so when I commented usually I'm giving my personal opinion and personal knowledge about how he can improve. So, that is one kind of ethics for me. I share my knowledge out.'

(Informant 2)

'My kind of ethics is that when I comment on YouTube I use harsh words but I don't use bad words.'

(Informant 3)

'That's why I'm not using lots of vulgar words and I will watching my grammars, my English, and it shows ethics because now people surmise, whoever using the good grammar he got good ethics.'

(Informant 4)

'Yes definitely, I make sure I do not use vulgar words as I am trying to send a message and create awareness, not create a problem.'

(Informant 5)

According to the answers of the informants above, the informants expressed that ethics has been a forgotten issue when it collides with anger. Other than that, it has also revealed that the ethics that informant practices are that he shares his knowledge on YouTube. Furthermore, two 
informants have said to be avoiding bad or vulgar words on YouTube. Finally, an informant sees ethics as the usage of correct grammar use when commenting on YouTube.

According to Bowen (2013), ethics is the idea of what is great, terrible, good, and bad. In webbased social networking, the correct ethic breaks even with the correct viewpoint. The correct intuition on the most proficient method to use online networking fittingly is the tendency to connect with individuals correctly. Therefore, it is certain that every YouTube user has their perception of what ethics are and how they reflect them on YouTube as comments.

The answers provided by the informants on the ethical consideration upon commenting on YouTube concluded as a recap in figure 1.1 below:

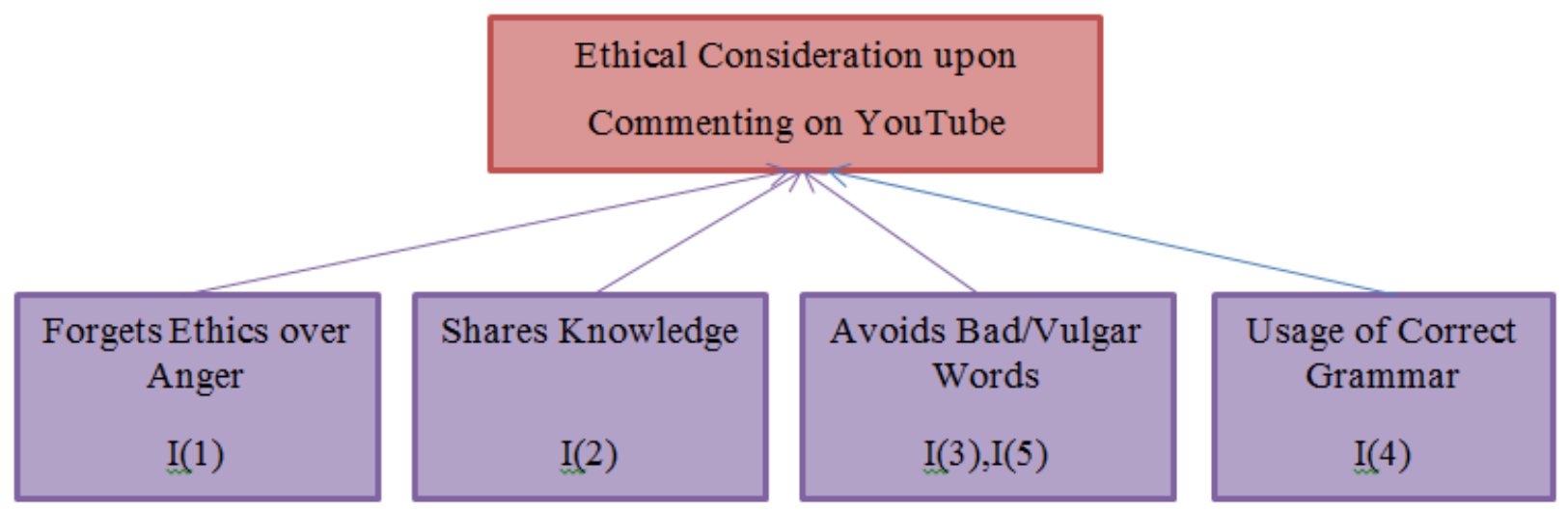

\section{Figure 1.1: Ethical Consideration upon Commenting on YouTube Recap}

\section{Theme 2: 'Do's and Don'ts' upon Commenting on YouTube}

'Do's and don'ts' in this concept are principles or beliefs concerning some action, as in commenting on YouTube and it is essential to gather data on this subject as it gives an idea to the researcher on the ethics or behaviors of the informants when commenting on YouTube. The following are the answers to the informants.

'But I have my own principle that I don't begin, or I don't start any racial comments by myself. This means I don't start up any racial, I shouldn't that is my principle, I shouldn't start up any racially related discussions or flaming, comments. When people flaming, I do comments, I do fight back and stuff. But for me my don't, in flaming, I don't start up any racially related topic.'

(Informant 1)

'What I don't is - I don't like to touch about the family stuff. Because, no matter if I'm arguing with another commenter, flamer, or I'm commenting on the celebrity. For me, the family is personal stuff.'

(Informant 2)

'I don't flame common peoples easily unlike celebrities.'

(Informant 3)

'I'll make sure I'm well known about the topic I'm defending before comment. Comment till the opposition give up and don'ts, don't give personal contacts.'

(Informant 4) 
'I'll do the comments but if let's say, that video is really will make an issue I will do not share it into my group.'

\section{(Informant 5)}

The informants of this research had revealed their 'do's and the don'ts' upon commenting on YouTube and it was according to their own beliefs and their comfort levels. According to Bernhardt and Gold (2014), when social media is used utilized hastily and rashly, there are the possibilities to the postponement, harm, or even obliterate one's expert and personal life.

An informant also admitted having to avoid revealing personal information on YouTube. According to Knapp (2016), one must remember that interpersonal organization happens in open space, with just the barest of systems giving any similarity of protection. Indeed, even harmless information imparted to the world can be unsafe in the wrong hands. He also adds that the best state of mind to take with a specific end goal to appreciate the advantages of person-to-person communication, while limiting the inalienable dangers, is to stay sceptical and cautious. Therefore, it is best to handle social media in a way that will not harm themselves and other users in any way through their behaviors and mindset.

The answers provided by the informants on the 'Do's and Don'ts' upon commenting on YouTube concluded as a recap in figure 1.2 below:

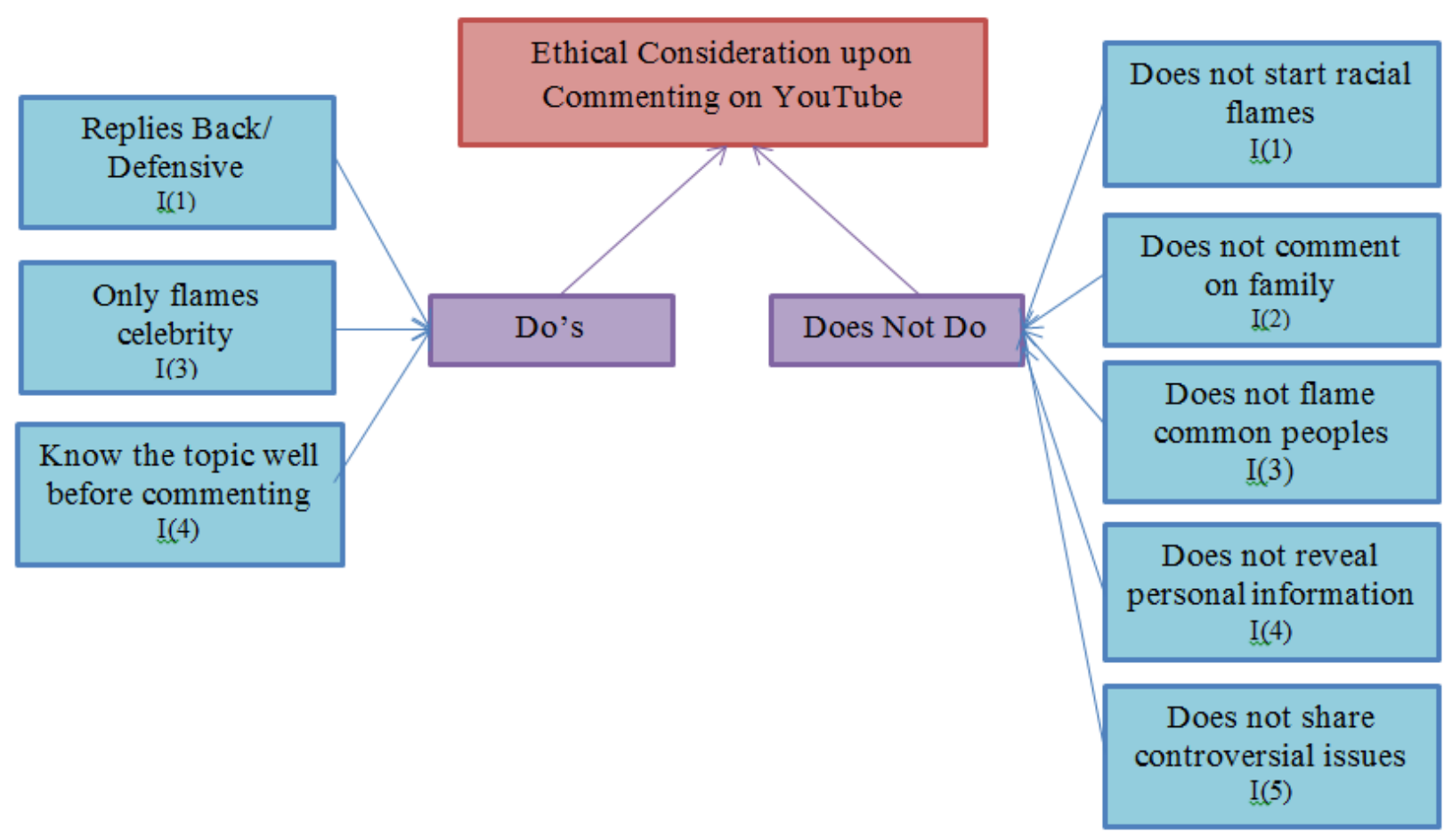

Figure 1.2: 'Do's and Don'ts' upon Commenting on YouTube Recap 


\section{Theme 3: The Awareness of the Laws Implemented in Malaysia on Cyber Security}

Cyber security, in general, is the condition of being ensured against the criminal or unapproved utilization of electronic information, or the measures are taken to prevent the threat and any misuse of the cyber world. In this section, the informants questioned on their opinions on a set of cyber security-related laws implemented in Malaysia. The Acts included in the guide are the Defamation Act 1957 (Amendment 2006), Sedition Act 1948 (Amendment 2006), Official Secrets Act 1972 (Amendment 2006), Printing Presses and Publications Act 1984 (Amendment 2012), Copyright Act 1987 (Amendment 2012), Security Offences (Special Measures) Act 2012 (Amendment 2015), and Communications and Multimedia Act 1998 (Amendment 2006). The following are the answers to the informants.

'Okay, basically almost $90 \%$ of laws that you explained, I have never heard of it before. And there are few like, copyright, security offenses, and communication and multimedia. Yes, I have heard about it but I don't really know how does the act really work and what is the, what it really do. Copyright. I have heard it a few times.'

\section{(Informant 1)}

'Yeah, I'm aware of that but I'm not fully acknowledged about it but I know certain things about it.'

(Informant 2)

'I think all the laws that have been implemented in this country are bullshit especially when it comes to - you know how the government is trying to control you? You can't say this, you can't say that. I think that is bullshit. I mean, we live in a democratic country so we should be able to say something unless it poses danger to others. I do think that almost - I think at least half of the sections in those Acts are irrelevant in today's society."

(Informant 3)

'No, I'm not aware of this Defamation Act, Sedition Act, and all Official Secret Acts. We just heard about this but we don't really know about this because nobody explains.'

(Informant 4)

'Okay, for example, the Communications and Multimedia Act. Okay. This is a really very upgrading technology and everything. Let's say, they can trace a person by Facebook or YouTube. When a person exposing something so they can trace the person so this Communications and Multimedia thing can trace the person and on that act, there is also some kind of-either the act so they can charge the person according to that act. Other than that, I don't know.'

\section{(Informant 5)}

Based on the answers of the informants above, almost all the informants have a lack of knowledge of the laws implemented on cyber security in Malaysia. This by far has been the reason behind their flaming activity. According to a study done by Nycyk (2016) on the enforcement of YouTube guidelines in web-based communities, the chances of those who flame on social media are higher when they are aware of the laws and regulations implemented 
on a certain subject. Hence, the hostility display on YouTube without understanding its implications and consequences that one might face if charged.

\section{Conclusion}

YouTube flamers have different ethical and legal perceptions on YouTube regarding flaming. They have an understanding of a certain ethics before flaming on YouTube. However, almost all the informants has a lack of knowledge of the laws implemented on cyber security in Malaysia especially on flaming on YouTube. Interestingly, the study findings show that the informants understand ethics on the Internet but lacks in the awareness on the laws implemented on flaming activities in Malaysia.

It is hoped that this study will contribute to the government such as the Communications and Multimedia Commission, MyCert and other policy makers to diversify efforts, campaigns, and activities to create ethical and legal awareness to the community or YouTube users. Flamers practices a certain ethics when indulging themselves in flaming activities and are aware of the existence of the laws of media in Malaysia. However, the level of flamers' knowledge of media laws are low. This is an important indicator to the government to provide awareness, knowledge, and understanding to flamers on ethics and media law. This awareness needs to be done by initiating various initiatives to increase flamers' knowledge of ethics and media law that is appropriate and not against the harmony and national unity policy of the nation. The government should also introduce artificial intelligence and apply restrictions on the usage of social media platforms to minimize flaming activities.

\section{Acknowledgment}

The authors wish to thank the Ministry of Higher Education Malaysia in funding this study under the Fundamental Research Grant Scheme (FRGS) S/O Code 13594, and Research and Innovation Management Centre, Universiti Utara Malaysia, Kedah for the administration of this study.

\section{References}

Bakardjieva, M., \& Gaden, G., (2012), "Web 2.0 Technologies of the Self," Philosophy and Technology, 25(3): 399-413.

Best, J. W., \& Khan, J. V. (2003). Research in education (9th Edition). New Delhi: PrenticeHall of India Private Limited.

Bernhardt, J. M., Alber, J., \& Gold, R. S. (2014). A social media primer for professionals: Digital dos and don'ts. Health Promotion Practice, 15(2), 168-172.

Briggle, A. (2008), "Real Friends: How the Internet can foster friendship," Ethics and Information Technology, 10(1): 71-79.

Bohman, J. (2008). The transformation of the public sphere: Political authority, communicative freedom, and Internet Publics. In M. J. van den Joven \& J. Weckert (eds.), Information technology and moral philosophy (pp. 66). Cambridge University Press.

Bourke, V. J. (1966). Ethics. New York: Macmillan.

Bowen, S. A. (2013). Using classic social media cases to distill ethical guidelines for digital engagement. Journal of Mass Media Ethics, 28(2), 119-133.

Boyd, d. (2006). Friends, Friendsters, and Top 8: Writing community into being on social network sites. First Monday, 11(12). Retrieved February 28, 2007 from http://www.firstmonday.org/issues/issue11_12/boyd/.

Cho D, Kim S. (2012). Empirical analysis of online anonymity and user behaviors: The impact of real name policy. In: Sprague RH, editor. 45th Hawaii International Conference on System Sciences (HICSS). 4-7 Jan 2012; Maui, HI IEEE. 
Cocking, D. \& Matthews, S. (2000). "Unreal friends," Ethics and Information Technology, 2(4): 223-231.

Computer Hope. (2018). Cyberlaw. Retrieved March 2, 2018 from https://www.computerhope.com/jargon/c/cyber-law.htm.

Creswell, J. W. (2012). Educational research: Planning, conducting, and evaluating quantitative and qualitative research. ( $4^{\text {th }}$ ed.). Boston, MA: Pearson.

Creswell, J, W. (2007). Qualitative inquiry and research design: Choosing among five approaches (2nd Edition), Thousand Oaks, CA: Sage.

Creswell, J. W. (1998). Qualitative inquiry and research design: Choosing among five traditions. Thousand Oaks, CA: Sage.

Dahlberg, L. (2001), "The Internet and democratic discourse: Exploring the prospects of online deliberative forums extending the public sphere," Information, Communication and Society, 4(4): 615-633.

Elgesem, D. (1996). "Privacy, respect for persons, and risk," in Philosophical Perspectives on Computer-Mediated Communication, C. Ess (ed.), Albany, NY: SUNY Press, pp. 4566.

Elpina, Henry Aspan \& Solly Aryza. (January, 2018). Effect perspective law in case social media Indonesia. IOSR Journal of Humanities And Social Science (IOSR-JHSS), 23(1) Ver. 2, 27-30. DOI: 10.9790/0837-2301022730.

Ess, C. (1996). "The political computer: Democracy, CMC and Habermas" in Philosophical Perspectives on Computer-Mediated Communication, (C. Ess, ed.), Albany, NY: SUNY Press, pp. 197-230.

Ess, C. (2005), "Lost in translation? Intercultural dialogues on privacy and information ethics," Ethics and Information Technology, 7(1): 1-6.

Ess, C. (2006). "Ethical pluralism and global information ethics," Ethics and Information Technology, 8(4): 215-226.

FindLaw. (2018). Understanding the legal issues for social networking sites and their users. Retrieved March 2, 208 from http:/technology.findlaw.com/modern-law-practice/understanding-the-legal-issues-forsocial-networking-sites-and.html.

Forum Asia. (2012a). Internet Censorship and Government Controls. Retrieved April 18, 2016 from http://www.forum-asia.org/uploads/press-release/2012/July/Freedom-ofExpression-and-Social-Media-LOWRES.pdf.

Forum Asia. (2012b). Criminalisation of Speech on the Internet and Social Media. Retrieved April 18, 2016 from http://www.forum-asia.org/uploads/pressrelease/2012/July/Freedom-of-Expression-and-Social-Media-LOWRES.pdf.

Frick, M. \& Oberprantacher, A. (2011), "Shared is not yet sharing, or: What makes social networking services public?" International Review of Information Ethics, 15: 18-23.

Friedersdorf, C. (2015), "How dangerous is end-to-end encryption?," The Atlantic, July 14, 2015, available online https://www.theatlantic.com/politics/archive/2015/07/nsaencryption-ungoverned-spaces/398423/.

Habermas, J., (1992/1998), Between facts and norms: Contributions to a discourse theory of law and democracy, Cambridge, MA: MIT Press.

Hamington, M. (2010), "Care ethics, friendship and Facebook," in Facebook and Philosophy, D.E. Wittkower (ed.), Chicago: Open Court, pp. 135-145.

Khan, M. L. (2017). Social media engagement: What motivates user participation and consumption on YouTube? Computers in Human Behavior, 66, 236-247.

Knapp, K. M. (2016). Do's and don'ts of social media in the federal government. The handbook of federal government leadership and administration: Transforming, performing, and innovating in a complex world, 288. Portland, United States: Routledge, Taylor \& Francis Inc. 
Kathryn, V., Xavier, D., \& Denzel, M. (2014). The path from new to viral: Understanding what makes videos go viral. Iconference 2014. Retrieved March 30, 2017 from https://www.ideals.illinois.edu/handle/2142/47367.

Kucuk, A. (April 27, 2015). The ethics of social media. Ethics. Retrieved January 9, 2018, from https://rampages.us/ashleykucuk/2015/04/27/the-ethics-of-social-media/

Lange, P. G. (2006). What's your claim to flame? First Monday, 11(9), September 2006, $\begin{array}{llll}\text { Retrieved } & \text { March } & 2018 & \text { from }\end{array}$ http://firstmonday.org/issues/issue11_9//ange/index.html.

Langos, C. (July, 2013). Cyberbullying, associated harm and the criminal law. Retrieved March 2, 2018 from. http://search.ror.unisa.edu.au/media/researcharchive/open/9915950167401831/53111 791520001831.

Light, B., McGrath, K., \& Griffiths, M. (2008), "More than just friends? Facebook, disclosive ethics and the morality of technology," ICIS 2008 Proceedings, Paper 193, Retrieved March 2, 2018 from http://aisel.aisnet.org/icis2008/193/.

Kayany, J. M. (1998). Contexts of uninhibited online behaviour: Flaming in social newsgroups on usenet. Journal of the American Society for Information Science, 12(49), 1135-1141.

Marturano, A. (2011). "The ethics of online social networks-An Introduction," International Review of Information Ethics, 16: 3-5.

Moor, J., (2008), "Why we need better ethics for emerging technologies," in Information Technology and Moral Philosophy, J. van den Hoven and J. Weckert (eds.), Cambridge: UK: Cambridge University Press, pp. 26-39.

Moor, P.J., Heuvelman, A., \&Verleur, R. (2010). Flaming on YouTube. Computers in Human behavior, 26, pp. 1536-1546.

MyCERT Incident Statistics. (2019, December). MyCert Malaysia Computer Emergency Response Team, MyCert. Retrieved April 28, 2020 from https://www.mycert.org.my/portal/statistics-content?menu=b75e037d-6ee3-4d118169-66677d694932\&id=0d39dd96-835b-44c7-b710-139e560f6ae0.

Nissenbaum, M. (2004). "Privacy as contextual integrity," Washington Law Review, 79(1): $119-157$.

Nycyk, M. (2016). Enforcing community guidelines in web-based communities: the case of flame comments on YouTube. International Journal of Web Based Communities, 12(2), 131-146.

O'Sullivan, Patrick, B \& Flanagin, A. (2003). Reconceptualizing 'flaming' and other problematic messages ". New Media and Society 5(1), 69-94.

Oxford University Press. (2018). Law. Retrieved March 2, 2018 from https://en.oxforddictionaries.com/definition/law.

Parsell, M., (2008), "Pernicious virtual communities: Identity, polarisation and the Web 2.0," Ethics and Information Technology 10(1): 41-56.

Puotinen, S., (2011), "Twitter cares? Using Twitter to care about, care for and care with women who have had abortions," International Review of Information Ethics, 16: 79-84.

Revathy a/p Amaderalimgam. (2015). Exploring the flaming culture on YouTube within the Malaysian context. Unpublished Report. Sintok: Universiti Utara Malaysia.

Reinig, B., Briggs, R., Brandt, S., \& Nunamaker, J. (1997). The electronic classroom on fire: Why it happens and how to put out the flames. Proceedings of the 30th Annual Hawaii International Conference on System Sciences, 2, 639-647.

Rost K,. Stahel L,. \& Frey, B.S. (2016) Digital social norm enforcement: Online firestorms in social Media. PLoS ONE 11(6): e0155923. https://doi.org/10.1371/journal.pone.0155923 Retrieved March 2, 2018 from 
http://journals.plos.org/plosone/article/file?id=10.1371/journal.pone.0155923\&type=p rintable.

Ryan, G. W., \& Bernard, H. R. (2000). Data management and analysis methods. In Handbook of qualitative research ( $2^{\text {nd }}$ ed.). Edited by N. Denzin and Y. Lincoln (pp. 769-802). Thousand Oaks,CA: Sage.

Salman, A. (2010). "ICT, the new media (Internet) and development: Malaysian experience." The Innovation Journal: The Public Sector Innovation Journal, 15(1), article 5. Retrieved December 29, 2011 from http://www.innovation.cc/volumes-issues/vol15no1.htm.

Saodah Wok \& Shafizan Mohamed. (2017). Internet and social media in Malaysia: Development, challenges and potentials. Retrieved March 2, 2018 from https://cdn.intechopen.com/pdfs-wm/55225.pdf.

Skog, D., (2011), "Ethical aspects of managing a Social network site: A disclosive analysis," International Review of Information Ethics, 16: 27-32.

Sinar Project. (2016). GE13 censorship of online media in Malaysia. Retrieved April 18, 2016 from http://sinarproject.org/en/updates/ge13-censorship-of-on-line-media-in-malaysia.

Siersdorfer, S., Chelaru, S., \& Nedjl, W. (2010). How Useful are Your Comments? Analyzing and Predicting YouTube Comments and Comment Ratings. Raleigh. NC, pp. 26-30.

Spence, E. (2011). Faith in reason: The unity of the right, the good and the good Life. In Hayden Ramsay and John Haldane (Eds.), Truth and Faith in Ethics. Exeter: Imprint Academic.

Steele, G., Woods, D., Finkel, R., Crispin, M., Stallman, R., \& Goodfellow, G. (1983). The Hacker's Dictionary. New York: Harper \& Row.

Stanford Encyclopedia of Philosophy. (2015). Social networking and ethics. Retrieved March 2, 2018 from https://plato.stanford.edu/entries/ethics-social-networking/.

Sunstein, C. (2008), "Democracy and the Internet," in Information Technology and Moral Philosophy, J. van den Hoven and J. Weckert (eds.), Cambridge UK: Cambridge University Press, pp. 93-110.

Tavani, H.T. (2005), "The impact of the Internet on our moral condition: Do we need a new Framework of ethics?" in The Impact of the Internet on our Moral Lives, R.J. Cavalier (ed.), Albany, NY: SUNY Press, pp. 215-237.

The Star. (2014, 24 February). Cyber-bullying reports up 55.6\% in 2013. Retrieved February 15, 2016 from http://www.thestar.com.my/news/nation/2014/02/24/cyber-bullying-up$55 \mathrm{pc} /$

Thye, L. L. (2017, April 11). On the Alert for Cyberbullying. The Star Online, Retrieved March 2,2018 from www.thestar.com.my/opinion/letters/2017/04/11/on-the-alert-forcyberbullying/.

Thompson, D. (2014, June 19). The Most Popular Social Network for Young People? Texting. Retrieved April 2, 2015, from www.theatlatic.com: http://www.theatlantic.com/ technolo gy/archive/2014/06/facebook-texting-teens-instagram-snapchat-mostpopular-social-network/373043/.

Vallor, S., (2010). Social networking technology and the virtues: Ethics and Information Technology, 12 (2): 157-170.

Van den Eede, Y. (2010). Conversation of mankind' or 'idle talk'?: A pragmatist approach to social networking sites," Ethics and Information Technology, 12(2): 195-206.

Wong, P.H., (2010). "The good life in intercultural information ethics: A new agenda," International Review of Information Ethics 13: 26-32.

Wong, P. H., (2012). "Dao, harmony and personhood: Towards a Confucian ethics of technology," Philosophy and Technology, 25(1): 67-86. 